INDO GLOBAL JOURNAL OF

PHARMACEUTICAL SCIENCES

ISSN 2249- 1023

\title{
A Recent Advancement in the Treatment of Peptic Ulcers using Herbal Medicines
}

\author{
Guprinder Kaur ${ }^{* 1}$, Pooja Sharma ${ }^{1,2}$, Dinesh Kumar ${ }^{1}$ \\ ${ }^{1}$ Sri Sai College of Pharmacy, Manawala, Amritsar-143115, Punjab, India \\ ${ }^{2}$ Department of Pharmaceutical Sciences and Drug Research, Punjabi University Patiala
}

Address for Correspondence: Gurpinder Kaur; gurpinderk362@ gmail.com

Received:
01.03.2019
Accepted:
25.03.2019
Keywords
Peptic ulcer,
Allylpyrocatecho
1, Gallic acid,
Gingerol.

Received:

Accepted:

Keywords

Peptic ulcer,

1, Gallic acid,

Gingerol.

\begin{abstract}
About $70 \%$ population suffering from peptic ulcer in worldwide. Peptic ulcer is disruption in the flow of the mucosa of stomach or duodenum. Endoscopy and Barium meal use for identify it. Herbal drugs which is used in the treatment of peptic ulcer are ginger, garlic, ocimum sanctum, liquorice, aloe vera, ficus religiosa and piper betel, azadirachta indica. We use herbal drugs they give best result than synthetic drugs. Herbal drugs decrease the side effects, effective in chronic reasons, low cost. Allylpyrocatechol is a phenolic compound which is obtained from Piper and it has been used in the treatment of peptic ulcer. Gallic acid is an organic compound that found in tea leaves, oak bark, sumac, gallnuts which gives effective activity in peptic ulcer treatment. Ginger contains gingerol which used for cure the peptic ulcer. Aloe vera have barbaloin and isobarbaloin acids which act as antiulcers. Ficus religiosa contains beta sitosterol and gluanol which help to cure the peptic ulcers. Liquorice carry a glycyrrihizinic acid used in treatment of peptic ulcers. Azadirachta indica has stearic acid and palmitic acid which is obtain from nimbidin constitutent of neem seeds. Ocimum sanctum contain a eugenol which have capacity to treat the peptic ulcers. (C) 2019 iGlobal Research and Publishing Foundation. All rights reserved.
\end{abstract}

Cite this article as: Kaur, G.; Sharma, P.; Kumar, D. A Recent Advancement in the Treatment of Peptic Ulcers using Herbal Medicines. Indo Global J. Pharm. Sci., 2019; 9(2Suppl.): 141. DOI: http://doi.org/10.35652/IGJPS.2019.92S39.

Indo Global Journal of Pharmaceutical Sciences( ISSN 2249 1023; CODEN- IGJPAI; NLM ID: 101610675) indexed and abstracted in CrossRef (DOI Enabling), UGC CARE Journal List, EMBASE(Elsevier), National Library of Medicine (NLM) Catalog, ResearchGate, Publons, CAS (ACS), Index Copernicus, Google Scholar and many more. For further details, visit http://iglobaljournal.com

This is a special issue as an outcome of 'RAPSCON-2019' sponsored by APTI and organized by Sri Sai College of Pharmacy, Manawala, Amritsar, Punjab, India. Relaxation offered in journal format. 